\title{
The Effect of Cooperative Learning Model in Social Science Class
}

\author{
Adi Purwanto, Mustaji, Ketut Prasetyo, Dyan Eka Pamungkas, Sukarman \\ Universitas Negeri Surabaya \\ Surabaya, Indonesia \\ padi90911@gmail.com
}

\begin{abstract}
This study aims to determine the effect of cooperative learning model on the fifth grade students' motivation of SD Negeri 2 Puter KembangabhuLamongan in social science learning process. This research uses a quasi-experimental design using Non-equivalent Control Group. The subjects of this research are $\mathbf{4 0}$ students of 2 class, that is class $V A$ as experiment class and class $V B$ as control class. The results show that the students who learn social science by using cooperative learning method simultaneously have a better learning motivation than those who learn social science by using conventional learning methods.
\end{abstract}

Keywords - Quasi-Experimental, Cooperative Learning Model of Make A Match Technique, Student Learning Motivation.

\section{INTRODUCTION}

Motivation is an impulse within an individual to do something. This motivation is an important factor for the students in the learning process. Someone who has a high learning motivation can be seen from how their attitude and enthusiasm during the learning activities take place. To see the attitude and enthusiasm of students, teacher can assess how much motivation of students in doing learning activities. To find out more detail how much the motivation of students, teacher can see it from several things such as perseverance students in learning, independence in doing the task, pay attention while the learning process takes place, the desire to succeed, not easy to give up in facing the problems [1].

Motivation is important for students in learning activities [2]. Teachers can design learning activities that can generate the student learning motivation. However, in reality there are many learning activities that build the students' boredom. One of the learning activities that students find boring is social studies (Suparta, Lasmawan, Marhaeni, 2015, pp. 4, interview results, opinions from Alfarisi VA, Elsa VB, Indriyani VB students SD Negeri 2 Puter Kembangbahu-Lamongan Lamongan on Thursday, March 23, 2018). This is because learning activities are oriented only on the material contained in textbooks and centered at the teachers. This affects the motivation of students in the social science learning process [3]. It can be concluded the main problem arises during the learning activity is the low motivation of student in learning.
Teacher as a learning organizer in the classroom has to realize that their role is a core in the learning process. Their role is not only to convey information to students but also to facilitate the students in developing their potential skills in the learning process. Teacher can create a good quality learning process by providing meaningful learning experiences and fostering the students' learning culture [4]. Therefore, it should be designed a fun learning model where the teacher does not dominate the class. The interaction between teacher and students in the learning process should exist. One of the learning model that can be used is cooperative learning model with make a match technique. Eggen and Kauchak in [5] argue that cooperative learning is a learning model involving students to work collaboratively to achieve common goals. Learning model with make a match technique is suitable to improve student's learning motivation [6]. Applying cooperative learning models with make a match technique can improve learning motivation because the students are given the opportunity to interact with the other students, the classroom learning can be created as a game and there is a competition among the students' groups in solving the problems related to the subject matter. The implementation of cooperative learning model with make a match technique can also increase student's learning activity, both cognitively and physically. The implementation of this model is expected that no more students surreptitiously play mobile phone or do other activities except learning. The students are required to actively seek out their partners and learned to understand the concepts of social science in a fun learning environment.

Based on the background that has been described above, the author is interested in conducting study by raising the title " The Effect of Cooperative Learning Model in Social Science Class". In general, the purpose of the study is to find out how big the effect of the implementation of cooperative learning model with make a match technique to the motivation of the students of class V in SD Negeri 2 Puter KembangbahuLamongan. This study aims to answer some problem formulation as follows: First, is there any difference in student's learning motivation in learning social science after applying cooperative learning model with make a match technique?. Second, is there any difference in student's learning motivation in social science learning after the implementation of conventional method?. Third, is there any difference in learning motivation between the students who 
taught by using the cooperative learning model with make a match technique and whodo not taught by using that model?

\section{METHOD}

The study method used in this study is a quantitative method with a quasi-experimental approach. Quasiexperiment according to Komalasari [6] is an experiment that has treatments, impact measurements, and experimental units, but does not use random placements. Quasi-experiment aims to estimate the condition of variables in circumstances and does not allow to control and manipulate all relevant variables. The design used in this study is Non-equivalent Control Group Design. The selection of this design is because the author is unable to strictly control the influx of external variables. The study design can be seen below.

Maintaining the Integrity of the Specifications

\begin{tabular}{|l|l|l|l|}
\hline Groups & Pre-test & Treatment & Post-test \\
\hline Experimental & $\mathrm{O}_{1}$ & $\mathrm{X}_{1}$ & $\mathrm{O}_{2}$ \\
\hline
\end{tabular}

TABLE 1. NON-EQUIVALENT CONTROL GROUP DESIGN

\begin{tabular}{|l|l|l|l|}
\hline Class & & $\mathrm{X}_{2}$ & \\
\hline \multirow{2}{*}{$\begin{array}{l}\text { Control } \\
\text { Class }\end{array}$} & $\mathrm{O}_{3}$ & $\mathrm{C}_{1}$ & \multirow{2}{*}{$\mathrm{O}_{4}$} \\
\cline { 3 - 3 } & & $\mathrm{C}_{2}$ & \\
\hline
\end{tabular}

Information :

$\mathrm{X}_{1}$ : The first treatment of social science learning using a cooperative learning model with make a match technique.

$\mathrm{X}_{2}$ : The second treatment of social science learning using a cooperative learning model with make a match technique.

$\mathrm{C}_{1}$ : The first treatment of social science learning using a conventional method.

$\mathrm{C}_{2}$ : The second treatment of social science learning using a conventional methods.

$\mathrm{O}_{1}$ : Pre-test is the initial data of students' learning motivation in the experimental class.

$\mathrm{O}_{2}$ : Post-test is the motivation to learn students after receiving treatment in the experimental class.

$\mathrm{O}_{3}$ : Pre-test is the initial data of student learning motivation in the control class.

$\mathrm{O}_{4}$ : Post-test is the students' learning motivation after the implementation of conventional method in control class.[7]

Instrument used in this study is non-test instrument that is questionnaire to measure student's learning motivation. A questionnaire is a list of questions given to others who are willing to respond (respondent) in accordance with user demand [1]. Dissemination of questionnaire aims to determine the level of student learning motivation before and after implementing cooperative learning method with make a match technique in the experimental class and conventional method in the control class.

Reliability test is a measurement showing the consistency of a measuring instrument [1]. Reliability test of a questionnaire in this study uses Cronbach's Alpha formula. Questionnaire test is filled by 30 respondents, the questionnaire is declared reliable if the calculation results are greater than 0.361 with $5 \%$ significance level. Instruments used in the study are tested the level of its validity using the formula Pearson Product Moment. Testing the instrument validity according to Arikunto [1] is a measurement showing the level of reliability or validity of a measuring instrument. Test data normality in this study uses the Kolmogorov-Smirnov Test method at SPSS.

Criteria of decision-making can be done based on probability (asymptotic significance). If the probability is $\geq$ 0.05 then the data distribution is normal whereas if the probability $<0.05$ then the data is not normally distributed. The normality of data obtained from the questionnaire of learning motivation before and after treatment in the experimental class and control class can be seen in the following table.

TABle 2. One-SAmPle Kolmogorov-Smirnov Test

\begin{tabular}{|ll|r|r|}
\hline & & Pretest-E & Post-test-E \\
\hline $\mathrm{N}$ & Mean & 30 & 30 \\
Normal & Std. & 37.37 & 46.40 \\
Parameters ${ }^{\mathrm{a}, \mathrm{b}}$ & Deviation & 3.873 & 4.280 \\
& Absolute & .165 & .122 \\
Most Extreme & Positive & .107 & .087 \\
Differences & Negative & -.165 & -.122 \\
Kolmogorov-Smirnov Z & .903 & .670 \\
Asymp. Sig. (2-tailed) & .388 & .760 \\
\hline
\end{tabular}

Test Results of Normality Student Motivation in Experimental Class

a. Test distribution is Normal.

b. Calculated from the data.

TABLE 3. ONE-SAMPLE KOLMOGOROV-SMIRNOV TEST

\begin{tabular}{|lr|r|r|}
\hline & & Pretest-K & Post-test -K \\
\hline $\mathrm{N}$ & & 30 & 30 \\
Normal & 38.10 & 38.63 & 46.40 \\
Parameters $\mathrm{a}, \mathrm{b}$ & 3.575 & 5.537 & 4.280 \\
& .129 & .112 & .122 \\
Most Extreme & .104 & .112 & .087 \\
Differences & -.129 & -.084 & -.122 \\
Kolmogorov-Smirnov Z & .707 & .615 \\
Asymp. Sig. (2-tailed) & .700 & .844 \\
\hline
\end{tabular}
Class

Test Results of Normality Student Motivation in Control

a. Test distribution is Normal.

b. Calculated from the data. 
Homogeneity test is conducted to see the level of similarity of student answers in the questionnaire. Homogeneity test is conducted by using variance test formula or F test, that is One Way ANOVA formula. If the value of significance $>0.05$ then it is the homogeneous data whereas if the significance value $<0.05$ then the data is not homogeneous. Results of data processing can be seen in the following table.

TABLE 4.TEST OF HOMOGENEITY OF VARIANCES

\begin{tabular}{|c|c|c|c|c|}
\hline & $\begin{array}{l}\text { Levene } \\
\text { Statistic }\end{array}$ & $\mathrm{dfl}$ & $\mathrm{df} 2$ & Sig. \\
\hline Pre-test & .212 & 1 & 58 & .647 \\
\hline Post-test & .812 & 1 & 58 & .371 \\
\hline
\end{tabular}

Hypothesis testing in this study uses independent sample t-test on SPSS 20. Hypothesis testing is conducted to determine whether or not there are differences in student learning motivation before and after treatments, that is the implementation of cooperative learning model make a match techniques in the experimental class and the implementation of conventional methods in the control class. If the significance value $>0,05$ then there is no difference of student's learning motivation before and after done treatment whereas if significance value $<0,05$ then there is difference of student's learning motivation before and after done treatment. The result of data processing of students' motivation of experiment class and control class can be seen in following table.

TABle 5. Hypothesis Test Motivation Student LEARNing ClASS EXPERIMENT AND CLASS CONTROL

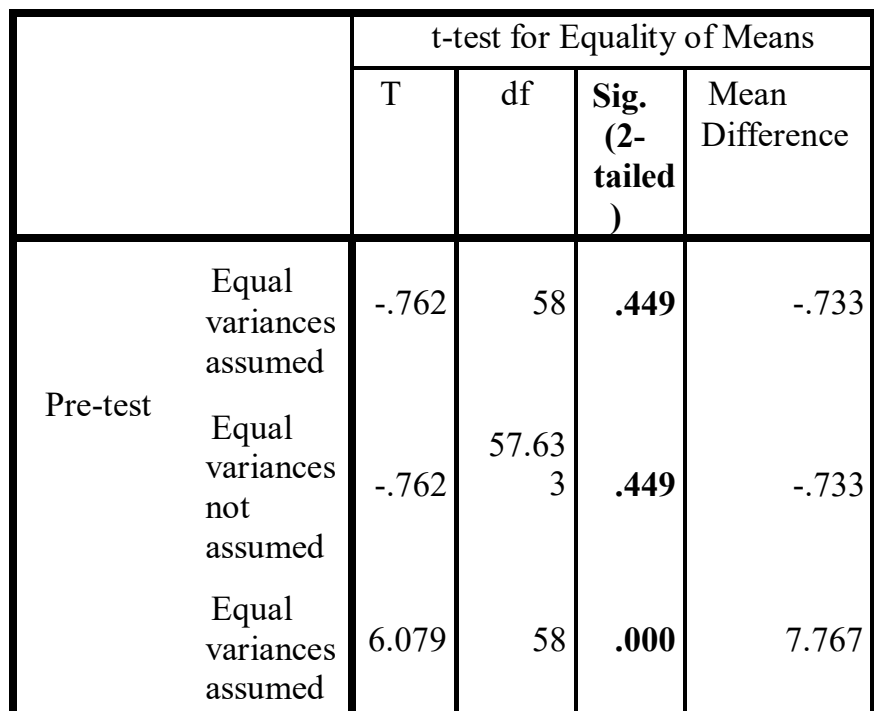

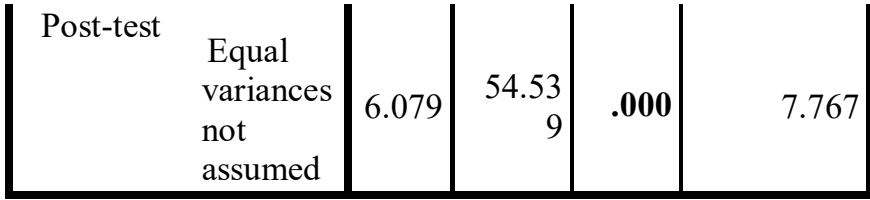

\section{RESULT AND DISCUSSION}

The purpose of this study is to find out how much the effect of the implementation of cooperative learning model with make a match techniques to motivate the students in class V SD Negeri 2 Puter Kembangbahu-Lamongan in social science learning.

\section{GRAPH 1. STUDENTS' LEARNING MOTIVATION IN EXPERIMENTAL AND CONTROL CLASS}

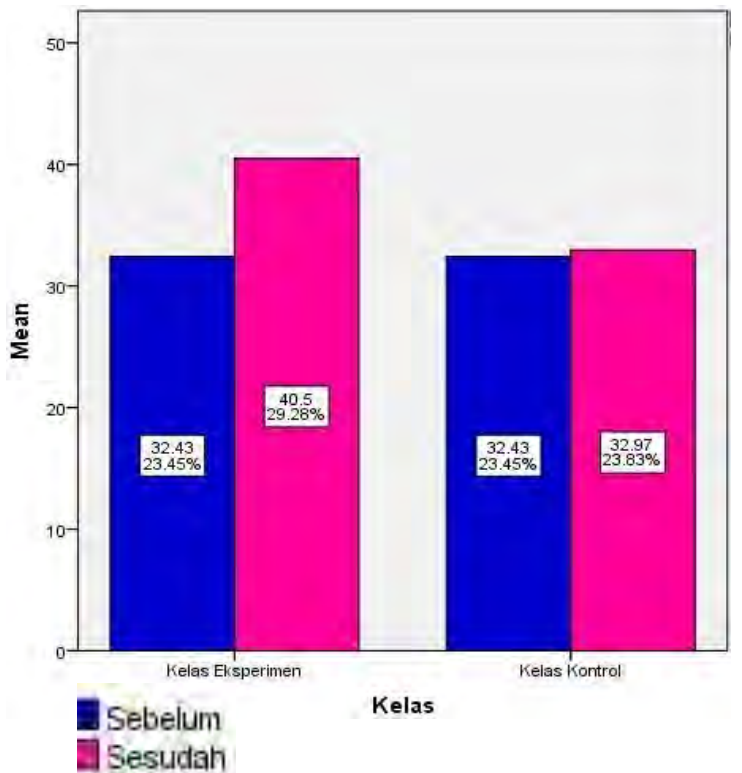

Based on the calculation of questionnaire score, it is known that there is difference of mean of student's learning motivation before and after implementation of treatment in the experimental class, that is by applying cooperative learning model with make a match technique. Prior to the treatment, the average learning motivation of students in the experimental class is 32.43 and after treatment, the average of student learning motivation increased to 40.5 , while there are not many differences about student's learning motivation in the control class students that the average before being treated is 32.43 and after given treatment, the average of student learning motivation is 32.97 . The average score before the treatment in the experimental class and control class has the same average of 32.43 , because the social science subject has not implemented cooperative learning model with make a match technique. Whereas after implementation of make a match technique in the experimental class, mean of student learning motivation is bigger than control class which do not apply make a match technique. This proves that the implementation of cooperative learning model with make a match technique in learning social science class $\mathrm{V}$ on the material tax system affect the student's learning motivation. 
Learning motivation is not easy to grow, so the efforts need to be able to cause the students desire to cultivate the motivation [8]. Therefore, teacher as parents of students at schools has a big role in fostering student learning motivation. One of the efforts that can be done by teacher to foster student's learning motivation is by making the learning atmosphere fun through the implementation of various learning model. The implementation of various learning model needs to be done because according to Dimyati [9], one of the factors that can influence student's learning motivation is the existence of dynamic elements in learning. A monotonous learning atmosphere can make students bored with the learning process and uninterested in learning the material.

The implementation of cooperative learning model with making a match technique has been proven to foster students' learning motivation because this technique is fun and there are elements of play in its implementation [6]. The increase of student learning motivation is seen from the fewer students who play mobile during the lesson. No students sleep when the teacher explains the material and the number of students who listen to the material explanation from the teacher and record the material rather than talking with friends is increasing. It can also be seen that the students will approach the desk of the teacher and ask to be re-explained the material that is not understood. This shows that students have a desire to try to find out the unintelligible material and show courage to ask people who understand the material better. The results of this study are in line with the opinions expressed by Riyanto which states as follows:

The implementation of cooperative learning model of type make a match shows high motivation which is characterized by the accuracy of looking for partner, good cooperation in doing task, courage in presenting the result, argue and ask.

The increase of student learning activity is also seen during make a match implementation where students look enthusiastic looking for each partner's card. Students try to find the pair of cards before the card-end time limit expires. The existence of deadline in the implementation of making a match technique is one way to train students' discipline in respecting time [6]. Student's discipline in using time is also seen while performing individual tasks. When getting the question, students immediately do the tasks and when it has finished, the students do not procrastinate to collect tasks to the teacher. The increase of student learning activity is an indication of the increased motivation of student learning and in accordance with the results of research from Lestina and Mashudi [10] which argue as follows.

Make a match technique learning model is more interesting learning process and makes most students more enthusiastic to follow the learning process. Student activeness can be seen at the time the students looking for their pair of cards. Indication of the increase in student learning motivation can also be seen from the percentage of liveliness and student learning outcomes.

The control class as a comparison class in the social science learning process in this study is given treatment using conventional method. After the implementation of conventional methods, students' learning motivation does not increase. Learning by listening to the explanation of the teacher and not involving the students to participate actively in the learning can cause a sense of boredom in students, so that students are not interested in learning and choose to do other activities that can repel boredom. Lasmawan [11] states the lack of conventional methods of student learning motivation as follows.

Condition with conventional learning model dominated by lectures will place the teacher as a source of information (Teacher Center) so that students are only as the object of learning that receives knowledge from teacher. Such learning conditions do not support students in improving their learning motivation in order to achieve optimal learning outcomes.

Therefore, it can be concluded that the implementation of conventional methods has not been able to improve students' learning motivation in social science learning in taxation material. When students are tired of listening to the material from the teacher, students will choose to do non-learning activities. The implementation of cooperative learning model with make a match technique can be concluded to improve students' learning motivation in social science learning by increasing student activity in learning such as increasing number of students who are able to give opinion or argue an increasing number of students who dare to ask questions related to material that is not understood. The implementation of cooperative learning model with make a match technique gives the opportunity for the students to do various activities and the learning process is not only limited to the listening activity of material explanation from the teacher. Lasmawan [11] states the implementation of conventional methods does not support students in improving their learning motivation, reinforces the results of this study that the implementation of cooperative learning model make a match technique is better than conventional methods in reminding students' learning motivation in social science learning.

\section{References}

[1] Riduwan, "Belajar Mudah Penelitian untuk Guru-Karyawan dan Peneliti Pemula," Bandung Alf., p. 97, 2007.

[2] W. J. K. Davies, Learning resources?: an argument for schools, vol. 1. Council for Educational Technology for the United Kingdom: Distributed by Councils and Education Press, 1975.

[3] K. P. Wibowo and M. Marzuki, "Penerapan Model Make a Match Berbantuan Media Untuk Meningkatan Motivasi Dan Hasil Belajar IPS," Harmon. Sos. J. Pendidik. IPS, vol. 2, no. 2, pp. 158-169, 2015.

[4] D. G. Suparta, I. W. Lasmawan, and A. A. I. N. Marhaeni, "Pengaruh Model Pembelajaran Kooperatif Teknik Make a Match Terhadap Motivasi Belajar Dan Hasil Belajar Ips," PENDASI J. Pendidik. Dasar Indones., vol. 5, no. 1, pp. 1-12, 2015.

[5] S. P. Trianto and M. Pd, "Model-model pembelajaran inovatif berorientasi Konstruktivistik," Jakarta: Prestasi Pustaka, 2007.

[6] K. Komalasari, "Pembelajaran kontekstual konsep dan aplikasi," Bandung: Refika Aditama, 2010.

[7] D. R. P. Sugiyono, "Metode Penelitian Administrasi Dilengkapi Dengan Metode R\&D," Revisi. Alf., 2009.

[8] Y. Miarso, Menyemai benih teknologi pendidikan. Kencana, 2004.

[9] M. Dimyati, "Belajar dan pembelajaran," Jakarta: Rineka Cipta, 2006. 
[10] M. Lestina and H. Mashudi, "Penerapan Model Pembelajaran Kooperatif Tipe Make A Match untuk Meningkatkan Motivasi," J. Pendidik. dan Pembelajaran, vol. 3, no. 3, 2016.
[11] W. Lasmawan, "Menelisik Pendidikan IPS dalam Perspektif KontekstualEmpiris,” Singaraja Mediakom Indones. Press Bali, 2010. 